\title{
Ground temperature monitoring for a coaxial geothermal heat exchangers field: practical aspects and main issues from the first year of measurements
}

\author{
Francesco Tinti ${ }^{1}$, Andrea Carri ${ }^{2}$, Sara Kasmaee ${ }^{1}$, Alessandro Valletta ${ }^{3}$, Andrea Segalini ${ }^{3}$, \\ Stefano Bonduà', Villiam Bortolotti ${ }^{1}$ \\ ${ }^{1}$ Department of Civil, Chemical, Environmental and Material Engineering of the University of Bologna, Via Terracini, 28 - 40131 Bologna, Italy \\ ${ }^{2}$ ASE S.r.l., Parco Area delle Scienze 181/a - 43124 Parma, Italy \\ ${ }^{3}$ Department of Engineering and Architecture of the University of Parma, Parco Area delle Scienze 181/a - 43124 Parma, Italy
}

\begin{abstract}
Ground temperature at shallow depths $(<50 \mathrm{~m})$ is not stable, nor in space, neither in time, and its behaviour is the result of the superimposition of effects of heat pulses of different origin: solar, geothermal and anthropic. The correct assessment of ground temperature is a crucial point when designing a shallow geothermal energy system. In geothermal closed loop projects using short borehole heat exchangers, the ground temperature has more variability and affects the rate of heat extraction/injection. Monitoring of the ground temperature can therefore be useful in ground source heat pump projects to correctly understand the behaviour of a shallow geothermal reservoir subjected to heat extraction/injection. This paper illustrates the practical aspects and main issues occurred in the installation, testing and working phases of a monitoring system realised to record ground temperature in a geothermal application. The case study is a field of eight coaxial borehole heat exchangers, $30 \mathrm{~m}$ long, connected to a novel prototype of dual source (air and ground) heat pump.
\end{abstract}

\section{Keywords:}

Geothermal energy, Ground Temperature, Borehole Heat Exchanger, Monitoring

\section{Introduction}

A closed loop geothermal circuit is designed to exchange heat with the ground within a specified volume (Eskilson, 1987). Rocks, soils and groundwater are used to provide heat to the buildings, generally by ground source heat pumps (GSHP), or to receive and store their excess heat (Magraner et al., 2010). Shallow geothermal systems are designed to allow operational repeatability over the years, thereby avoiding thermal depletion of the soil (Focaccia et al., 2016). Due to the insulation from ambient weather, underground temperature is stable, thus enhancing the efficiency and capability of the energy transfer in the heat pumps (Florides et al., 2013). The standard depth of a vertical closed loop borehole heat exchanger lies between 50 and $150 \mathrm{~m}$, allowing a high portion of heat exchange surface to be in contact with aquifers, soils and rocks at a stable temperature (Aresti et al., 2018). Drilling work down to $50 \mathrm{~m}$ depth and beyond is the major cost of the entire system and it negatively impacts the market of shallow geothermal components: geo-exchangers and GSHP (Tinti et al., 2016). Several countries and regional administrations

Corresponding author: Francesco Tinti

francesco.tinti@unibo.it put into action incentives and environmental laws to support the diffusion of this kind of environmentally friendly energy technology (Giambastiani et al., 2014). Mature markets exist in some countries, such as Sweden, Netherlands and Germany, but the GSHP systems are far from becoming an air conditioning standard technology. This is mainly due to the competition with district heating and cooling, natural gas boilers and air source heat pumps, which are environmentally friendly as well. The competition is becoming harder in recent years because of improvements in machinery efficiency. Therefore, new solutions had to be thought of, implemented and tested on the geo-exchanger components, too.

Coaxial borehole heat exchangers (CBHE) are particularly suitable to be installed at low depths, thus reducing installation costs. The heat exchange surface is bigger with respect to single-U or double-U pipe BHE, but the reachable depth is limited. The H2020 GEO$\mathrm{TeCH}$ Project aims to further decrease the installation costs of CBHE, by efficiently adapting to GSHP specificities in regard to the hollow stem auger drilling technology, for the replacement of standard drilling techniques in alluvial plains (Tinti et al., 2018). A second GEO$\mathrm{TeCH}$ innovation, the dual source (air and ground) heat pump (DSHP), was supposed to be integrated with 
CBHE, for a further decrease in installation costs. Using DSHP, it is theoretically possible to undersize the CBHE field thanks to the combined use of air and ground sources. The active length of vertical CBHE, in contact with aquifers at stable ground temperature, can then be reduced, too. In consequence, the ambient seasonal variability can no longer be neglected. As an example, at least $30 \%$ of the active length of a $50 \mathrm{~m}$ deep CBHE, is located above the "neutral zone," the layer where ground temperature is not disturbed by ambient seasonality. This means that at least $30 \%$ of CBHE works with timevarying temperatures of the ground (Kurevija and Vulin, 2010).

Many knowledge gaps still exist for the correct design of DHSP linked to CBHE. Among them, it is worth noticing the following:

- How does the ground behave in the presence of strong, unconventional, heat pulses (higher than in standard BHE design) but interspersed with frequent shutdowns (because of the activation of an air source)?

- What will the efficiency of the DSHP be on the short and long term? Will it be smaller, similar or higher than the standard GSHP?

- To what extent will the impact of ambient seasonal variability on efficiency of the system be? Will the negative impact of time varying temperature during DSHP ground working mode be bigger than the positive recovery to natural state during the DSHP air working mode?

The CBHE behaviour can be accurately reproduced by simulating both the short-term and long-term response of the shallow geothermal reservoir. The short-term response is especially important in systems with high on/off operations, such as DSHP ones. For this purpose, the temperature variation of the surrounding ground must be well predicted, and it will depend both on the heat injected or extracted, and also on the ground thermal properties and the operating conditions of the BHE.

The thermal response of the ground and the amount of soil affected by the heat injection during a specific time period can be calculated and simulated in different ways. As an example, a possibility is to add a number of radial ground nodes and discretize the soil mass in small radial steps until the far-field radius (the "penetration radius"), where the effect of the heat injection vanishes. When numerically modelling the heat transfer between a BHE and the ground, for each specific time period, the correspondent penetration radius should be suitable to allow reproducing the behaviour of the system accurately (Ruiz Calvo et al., 2015). For this purpose, experimental measurements (temperature and flow) of circulating fluid inside the CBHE system and measurements of the ground temperature at different distances from its centre are necessary.

Monitoring ground temperature is an important issue in the shallow geothermal sector, both for research and professional purposes. Due to technology advancements and a decrease in costs, electronic measurement, registration and data transmission systems have been widely applied for many purposes, such as the validation of models (Tinti et al., 2017; Badenes et al., 2017), the control of system behaviour and efficiencies (Montagud et al., 2011) and the management of the resource by local and regional environmental authorities (Hähnlein et al., 2013).

This paper shows the practical aspects and main issues arisen of a monitoring system of ground temperature installed on the first prototype of DSHP connected to CBHE of the GEOTeCH Project (www.geotech-project.eu), whose results will be used for the validation of the coaxial borehole heat exchanger model.

\section{Materials and methods}

\subsection{Monitoring system used}

To validate the models of DSHP fed by CBHE, a monitoring system of ground temperatures was prepared. The system is installed on-site to monitor the ground temperature and consists of an innovative tool, called Therm Array, based on Modular Underground Monitoring System (MUMS) technology developed by ASE S.r.l. This approach relies on a combination of sensors embedded in specifically moulded nodes, called Links, connected by an aramid fibre and an electrical cable, thus forming an arbitrary long chain (Segalini et al., 2013; Segalini et al., 2014). Links can be customized, according to the situation, with different sensors able to record quantities such as displacements, water level variations and temperature. The whole monitoring apparatus is connected to an ASE801 Control Unit, which queries each different Link with an appropriate sampling frequency that could be changed accordingly to the monitoring needs (see Figure 1). Data collected is stored locally on a memory unit and sent to the mainframe server at the elaboration centre, where it is stored in a dynamic MySQL database with a daily multilevel backup system. Upon arrival on the central server, raw data is automatically elaborated and converted into physical units with a proprietary software routine specifically de-

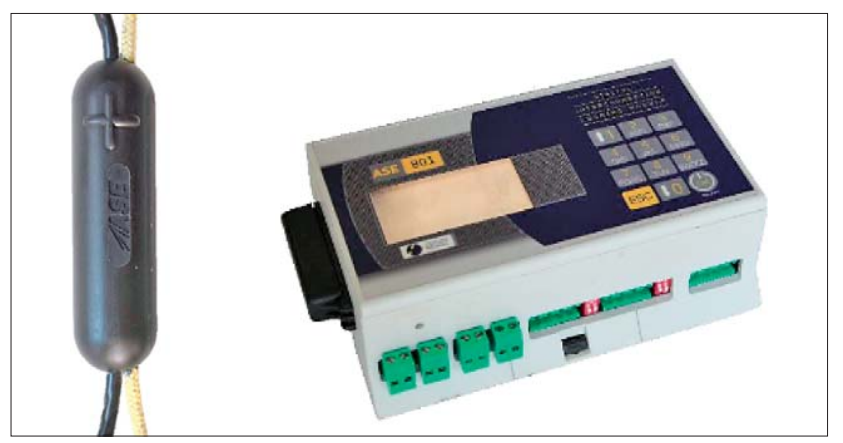

Figure 1: Therm Link, with fibre aramid (yellow) and quadrupole electrical (black) cables and ASE 801 Datalogger 
veloped for this purpose. The results are stored in a "parallel" database from which they can be accessed and analysed thanks to a dedicated web-based platform with private access, together with an FTP transmission to the end user.

In particular, the Therm Array presented in this paper equips a high-resolution thermometer (Therm Link) specifically designed for geothermal applications where it is necessary to monitor the soil temperature at different depths with high resolution. The sensor calibration is carried out thanks to a climate chamber where the instrumentation can be tested at different temperatures. The accuracy of the Therm Link is $\pm 0.5^{\circ} \mathrm{C}$ on an operating range of -40 to $+105^{\circ} \mathrm{C}$; the resolution is $0.0078^{\circ} \mathrm{C}$ and the measure repeatability is $\pm 0.015^{\circ} \mathrm{C}$. It should be underlined that the resolution of the thermometer implemented in the monitoring system has particular relevance in this specific case study, since the instrumentation's main purpose is the measurement of temperature variations. In addition to the monitoring system previously presented, PT100 Class $A$ thermoresistance probes were installed in order to monitor the temperature of water within the pipes flowing inside the geothermal field. These sensors operate according to the resistance measurement principle, relying on the fact that the material composing the probe features a well-known resistance-temperature relationship. In particular, as far as the PT100 sensors are concerned, this relationship is defined by an approximately linear trend, with a tolerance of $0.15^{\circ} \mathrm{C}$ at $0^{\circ} \mathrm{C}$. (www.capitindustria.eu)

\subsection{Tribano demo site}

The first prototype of new technology, together with appropriate monitoring, is located in the alluvial Po Plain, in the car park area adjacent to the HIREF S.p.A. factory (the producer and tester of DSHP), in Tribano (Province of Padua, Italy). In the Veneto Region, the use of pure water, as a circulating fluid, is generally better accepted instead of additive water. When additives are necessary, only the use of propylene glycol is allowed, with a maximum concentration of $20 \%$ in volume. Distinctions in terms of legal authorization requests exist in Italy between vertical drilling shallower or deeper than $30 \mathrm{~m}$. Moreover, when the drilling depth is more than 30 $\mathrm{m}$, geologists should send information about the crossed soil layers to the National Institute for the Environmental Protection and Research (ISPRA - Istituto Nazionale per la Protezione e la Ricerca Ambientale) in Rome, according to the Italian Law 464/84 (Gazzetta Ufficiale della Repubblica Italiana, 1984). In the Tribano demo site, propylene glycol is not used and the drilling depth is $30 \mathrm{~m}$. Furthermore, the demo site is located far away from the two groundwater source protection areas of the Padua Province: High Padua (supplying drinking water to the city) and Euganean Hills (with natural thermal springs). The geology of the study area is comprised in the shallowest layers of unconsolidated, alluvial soils, with very fine grain size - silt and clay - of low permeability, locally interspersed by sandy layers of thickness: $10 \mathrm{~m}$ (8-18 m depth), $5 \mathrm{~m}$ (21-26 m depth), $3 \mathrm{~m}$ (44-47 $\mathrm{m}$ depth) and $16 \mathrm{~m}$ (58-74 $\mathrm{m}$ depth) (Pomarin, 2017). A phreatic aquifer can be found at around $2.0 \mathrm{~m}$ below the ground surface; a series of overlapped confined aquifers are crossed starting from a depth of $50 \mathrm{~m}$. A hydrogeological study proved that drilling down to $30 \mathrm{~m}$ only crosses phreatic aquifers of poor quality, not suitable for drinking uses. Grouting was therefore not necessary for this geothermal system. However, its addition is always suggested to ensure a good thermal contact between the BHE and the ground. At the moment of the prototype installation, the GEOTeCH hollow stem auger drilling system was still not equipped with grouting devices. So, for this installation, grout was not injected and the procedure implied the ground collapsing around each CBHE, after removal of the drilling rods, which contained it. Due to low permeability of sediments along the borehole length, a significant thermal impact due to advection phenomena for groundwater movement is not expected. Finally, the Tribano demo site is not in a potential area of archaeological findings. The material excavated from the boreholes was mostly very fine sand with some clayey banding in the top of the borehole. All 8 CBHEs were connected to flow and return headers in the concrete collector pit. After the complete assembly of the borehole heat exchanger pipes, the whole system was flushed with water and pressure tested up to 6 bars. The demo site technical specifications are reported in Table 1.

Furthermore, 3 additional observation boreholes (OB) were realized to $15 \mathrm{~m}$ depth. They were equipped with pipes type PE100 SDR11 OD63, with the scope of hosting the Therm Links. The three OBs were installed in a straight line, two west (OB 1 and $\mathrm{OB} 2$ ) and one east (OB 3 ) to BHE 8 . This configuration was chosen in order to have control points for the definition of penetration diameters, according to the coaxial borehole heat exchanger thermal modelling of Cazorla et al., 2018. BHE 8 was selected being at the eastern vertex of the borehole heat exchanger field. In that way, OB 1 and OB 2, west to BHE 8 , are located inside the area influenced by heat transfer between BHE and the ground. On the contrary, OB 3, east to BHE 8, is located at the external border of the influenced area. OB 1 is located exactly in the middle between BHE 6 and BHE 8, so major phenomena of superimposition of thermal effects are expected to be measured and registered in the long term. OB 2 is located as close as possible to BHE 8, with the aim to measure and register heat wave behaviour around the BHE for the definition of the penetration diameter. OB 3, located three meters away from the borehole heat exchanger field, is used as reference point of the undisturbed ground thermal behaviour; no significant temperature changes from natural sinusoidal behaviour are ex- 
Table 1: Tribano geothermal heat pump demo technical specifications

\begin{tabular}{|c|c|}
\hline \multicolumn{2}{|c|}{ Technical specifications } \\
\hline $\begin{array}{l}\text { Coaxial } \\
\text { Borehole } \\
\text { Heat } \\
\text { Exchanger } \\
\text { CBHE }\end{array}$ & $\begin{array}{l}\text { Absence of grouting: } \\
\text { - Borehole filled with soil collapsed } \\
\text { when removing drill rods } \\
\text { - Dry pellets released from the top, to } \\
\text { contain intrusion of rainwater and } \\
\text { pollutants } \\
\text { Drill bit outer diameter (OD): } 170 \mathrm{~mm} \\
\text { Drill rod outer diameter: } 135 \mathrm{~mm} \\
\end{array}$ \\
\hline Outer pipe & $\begin{array}{l}\text { Type: PE100 SDR17 } \\
\text { Diameter: } 90 \mathrm{~mm} \\
\text { Thickness: } 5.4 \mathrm{~mm} \\
\text { Length: } 30 \text { meter coiled } \\
\text { Number of coils: } 8\end{array}$ \\
\hline Inner pipe & $\begin{array}{l}\text { Type: PP SDR } 11 \\
\text { Diameter: } 63 \mathrm{~mm} \\
\text { Thickness: } 5.8 \mathrm{~mm} \\
\text { Length: } 30 \mathrm{~m} \text { assembled in welded bars } \\
\text { Length of bars: } 4 \text { meters } \\
\text { Number of bars: } 7.5\end{array}$ \\
\hline $\begin{array}{l}\text { Geometry } \\
\text { of CBHE } \\
\text { field }\end{array}$ & $\begin{array}{l}\text { Number of CBHE: } 8 \\
\text { Displacement geometry: Rectangular } \\
\text { Distance among CBHE: } 6 \mathrm{~m} \\
\text { Type of connection: parallel } \\
\text { Number of CBHE lines: } 8 \\
\text { Type of CBHE line: PE100 SDR } 11 \text { DN32 } \\
\text { Type of connections: electrofusion welding } \\
\text { couplings }\end{array}$ \\
\hline Centralizers & $\begin{array}{l}\text { Number of centralizers: } 15 \\
\text { Distance between two centralizers: } 2 \mathrm{~m}\end{array}$ \\
\hline $\begin{array}{l}\text { Dual Source } \\
\text { Heat Pump } \\
\text { DSHP } \\
\end{array}$ & $\begin{array}{l}\text { Hybrid machine able to select whether using } \\
\text { ground or air source } \\
\text { Localized } 20 \mathrm{~m} \text { far from CBHE collector }\end{array}$ \\
\hline $\begin{array}{l}\text { Nominal } \\
\text { power }\end{array}$ & $\begin{array}{l}\text { Heating: } 16 \mathrm{~kW} \\
\text { Cooling: } 14 \mathrm{~kW}\end{array}$ \\
\hline $\begin{array}{l}\text { Working } \\
\text { period }\end{array}$ & $\begin{array}{l}\text { Heating: } 15^{\text {th }} \text { October }-15^{\text {th }} \text { April, } 14 \text { hours } \\
\text { per day } \\
\text { Cooling: } 15^{\text {th }} \text { May }-15^{\text {th }} \text { September, } 10 \\
\text { hours per day }\end{array}$ \\
\hline Tanks & $\begin{array}{l}\text { Number of tanks: } 2 \\
\text { - DHW buffer tank: } 3001 \\
\text { - Expansion tank: } 181 \\
\end{array}$ \\
\hline $\begin{array}{l}\text { Circulation } \\
\text { pumps }\end{array}$ & $\begin{array}{l}\text { Number of pumps: } 3 \\
\text { Max delivery head: } 12 \mathrm{~m} \\
\text { Max volume flow: } 10 \mathrm{~m}^{3} / \mathrm{h} \\
\text { - Ground Circuit } \\
\text { - User Circuit } \\
\text { - DHW circuit }\end{array}$ \\
\hline Sensors & $\begin{array}{l}\text { Number of pressure sensors: } 3 \\
\text { - Ground Circuit } \\
\text { - User Circuit } \\
\text { - DHW circuit } \\
\text { Number of flow sensors: } 3 \\
\text { Nominal flow: } 5 \mathrm{~m}^{3} / \mathrm{h} \\
\text { - Ground Circuit } \\
\text { - User Circuit } \\
\text { - DHW circuit }\end{array}$ \\
\hline
\end{tabular}

pected to be measured by Therm Arrays located in OB 3 . Along each observation borehole, a Therm Array with 4 Therm Link was inserted. The four Therm Links were positioned at depths of 2, 5, 10 and $15 \mathrm{~m}$ each. Unfortunately, the pipe installed in OB 3 could not reach the same depth of OB 1 and OB 2, but it stopped half a meter above. In OB 3, Therm Links were correctly positioned at 2, 5 and $10 \mathrm{~m}$, while the last Therm Link was laid down at pipe bottom. Finally, in order to correctly relate ground thermal behaviour with effective working of DHSP system, four measurement points on the circuit have been installed, by the use of PT100 sensors. PT100 have been installed: two on the head of BHE 8 (inlet and outlet) and two on the collector (inlet and outlet), the last two measuring the mixed water temperature from/to the 8 BHEs. The details and geometry of the monitoring system installed in Tribano is presented in Table 2.

Table 2: Geometrical details of monitoring system installed

\begin{tabular}{|l|l|}
\hline Therm Links & 12 \\
\hline $\begin{array}{l}\text { Number of } \\
\text { Therm Links }\end{array}$ & 3 \\
\hline Number of OB & $2-5-10-15$ (bottom of OB) \\
\hline $\begin{array}{l}\text { Depths of } \\
\text { installation } \boldsymbol{D} \text { (m) }\end{array}$ & Pure water \\
\hline Filling material & $\begin{array}{l}\text { OB 1: At half distance between BHE 6 } \\
\text { and } 8 \\
\text { OB 2: } 1 \mathrm{~m} \text { far from BHE 8 } \\
\text { OB 3: } 3 \mathrm{~m} \text { far from BHE } 8\end{array}$ \\
\hline PT 100 & $\begin{array}{l}\text { BHE } 8 \text { head: } 1 \text { inlet circuit / 1 outlet } \\
\text { circuit } \\
\text { Collector head (COL): } 1 \text { inlet circuit / } \\
1 \text { outlet circuit }\end{array}$ \\
\hline Number of PT100 \\
\hline $\begin{array}{l}\text { Location of } \\
\text { PT100 }\end{array}$
\end{tabular}

Figure 2 shows the map of Tribano demo site, with evidence of location of 8 BHEs, 3 OBs, COL and DSHP. Figure 3 shows the details of installation.

\section{Results}

The monitoring system started operating from midNovember 2017, with an acquisition frequency of 5 minutes. This frequency was chosen to detect the intervals of switching on and off operations of the DSHP ground circuit. Therefore, from the $15^{\text {th }}$ of November 2017, it was possible to monitor the ground thermal behaviour. Figure 4 reports the ground temperature monitored from the $15^{\text {th }}$ of November 2017 to the $15^{\text {th }}$ of September 2018 (10 months).

Values of circuit temperature monitored by PT100 should be shown together with the working data of heat pump and are not the object of this paper. 


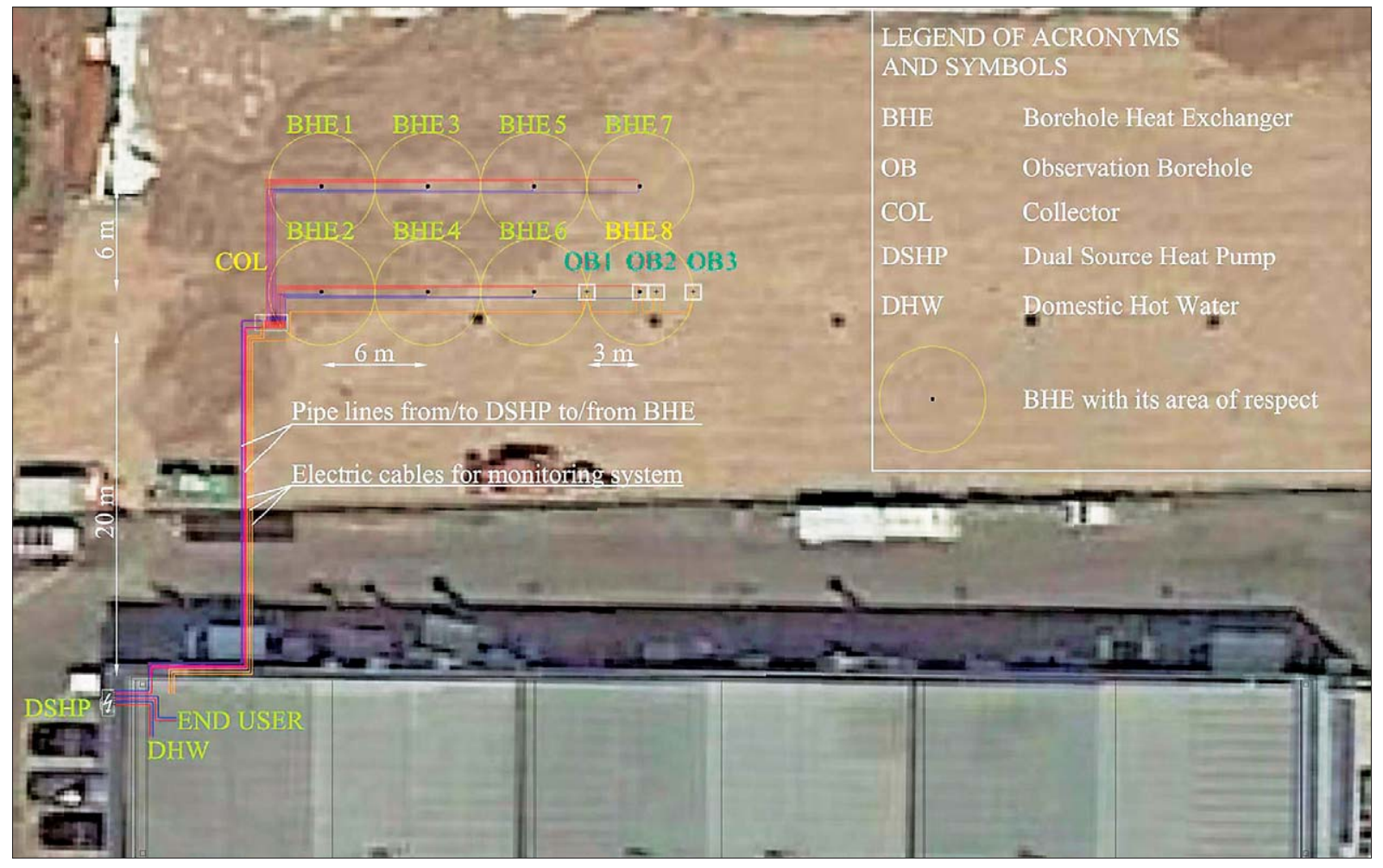

Figure 2: Map of geothermal demo site of Tribano. Therm Arrays of monitoring system are located in OB 1, OB 2 and $\mathrm{OB}_{3}$ (blue). PT1oo are located on the head of BHE 8 and COL (yellow).

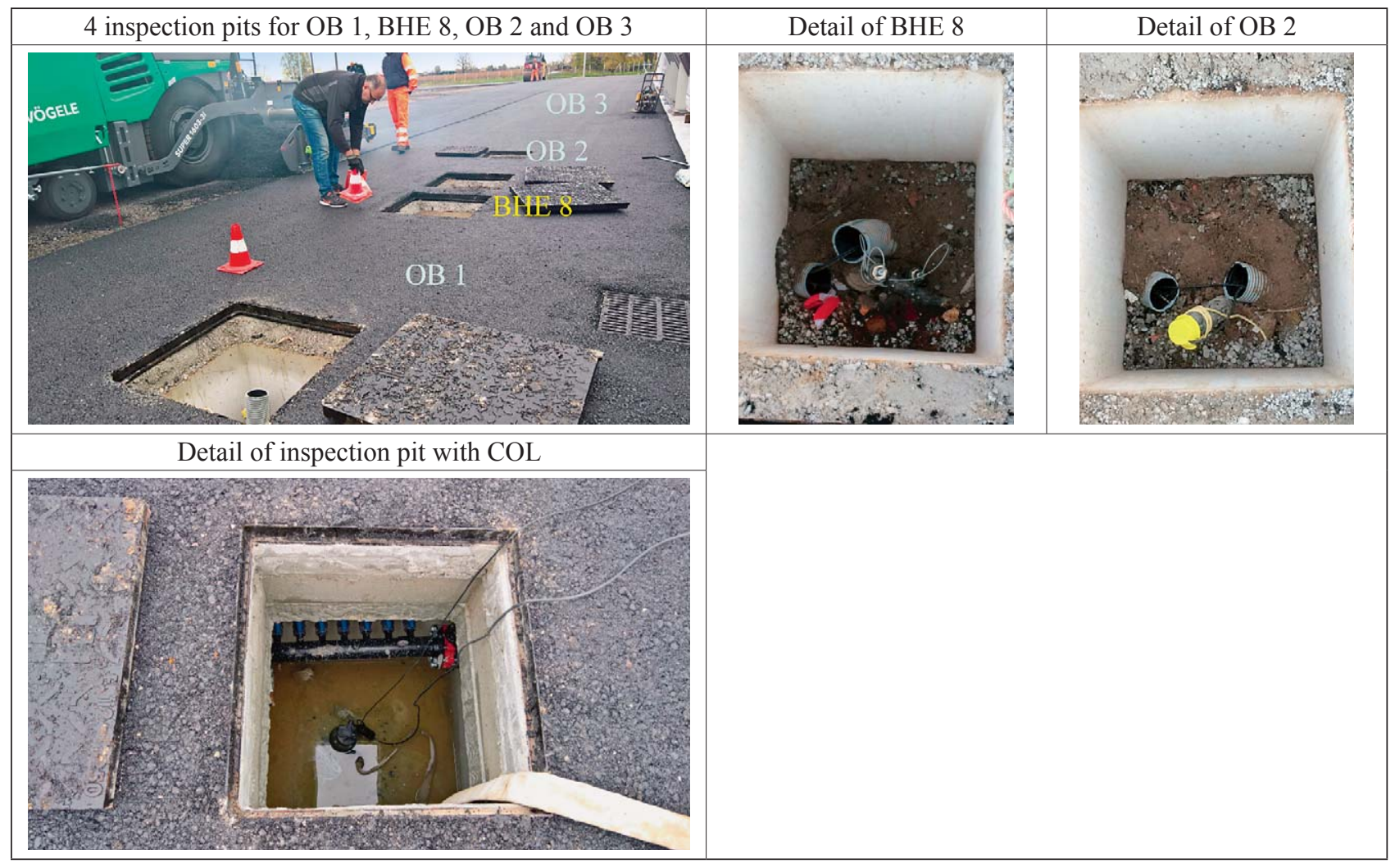

Figure 3: Photos from geothermal demo site of Tribano: location of observation boreholes and BHE 8 (upper left), details of heads of BHE 8 and one OB (upper right), detail of the inspection pit for the central collector, connecting all 8 BHE lines in one unique pipe linked to the DSHP (lower left). 

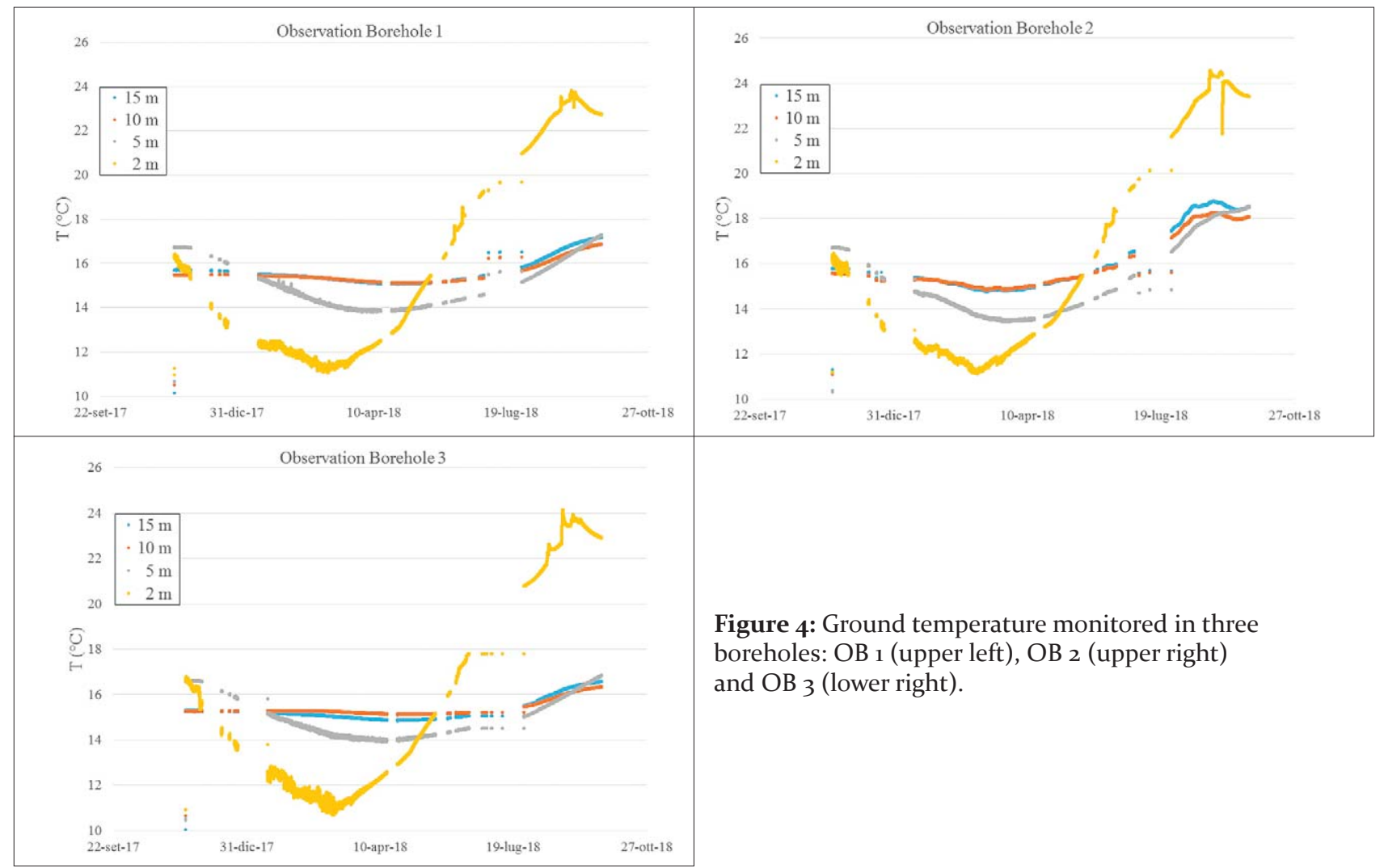

\section{Discussion}

Ground temperature measured waves apparently have the same space-time behaviour in the three $\mathrm{OB}$, and respect the typical sinusoidal model of Equation 1 (Baggs, 1983).

$$
\begin{gathered}
T_{g}=T_{m}-A_{e} \cdot \exp \left[-z \cdot \sqrt{\left(\frac{\pi}{365 \cdot \alpha_{g}}\right)}\right] . \\
\cos \left[\frac{2 \cdot \pi}{365} \cdot\left(t-t_{T_{0}}-\frac{z}{2} \cdot \sqrt{\frac{365}{\pi \cdot \alpha_{g}}}\right)\right]+\frac{h_{f}}{\lambda_{g}} \cdot z
\end{gathered}
$$

Table 3 reports all terms and symbols of Equation 1, with values from the Tribano demo site, useful to feed the analytical model.

By inserting the climate data of Tribano in Equation $\mathbf{1}$, the thermophysical properties of ground layers (down to $15 \mathrm{~m}$ ) and the geothermal heat flow in the area, the results of the ground temperature model do not match with the measurements (see Figure 5).

It was necessary then to analyse the curves separately. Three different data sets were tested:

1. Ground temperature at $2 \mathrm{~m}$ depth seems to be following a sinusoidal behaviour with an average of $17.5^{\circ} \mathrm{C}$, amplitude $6.5^{\circ} \mathrm{C}$ (which means, using the analytical model, an ambient amplitude of $10.5^{\circ} \mathrm{C}$ ) and a time of a minimum of 40 days. By using such
Table 3: Terms of Equation 1, with symbols, units and values taken from Tribano demo site.

\begin{tabular}{|l|l|l|l|}
\hline Term & Symbol & Unit & $\begin{array}{l}\text { Value } \\
\text { (Tribano } \\
\text { demo site) }\end{array}$ \\
\hline $\begin{array}{l}\text { Average ambient } \\
\text { temperature }^{1}\end{array}$ & $T_{m}$ & ${ }^{\circ} \mathrm{C}$ & 13.8 \\
\hline Ambient amplitude $^{1}$ & $A$ & ${ }^{\circ} \mathrm{C}$ & 15.5 \\
\hline $\begin{array}{l}\text { Time of minimum } \\
\text { temperature }\end{array}$ & $t_{0}$ & Days & 5 \\
\hline $\begin{array}{l}\text { Equivalent ground thermal } \\
\text { diffusivity }\end{array}$ & $\mathrm{a}_{g}$ & $\mathrm{~m}^{2} / \mathrm{d}$ & 0.125 \\
\hline $\begin{array}{l}\text { Equivalent ground thermal } \\
\text { conductivity }\end{array}$ & $1_{g}$ & $\mathrm{~W} /(m \cdot K)$ & 2.7 \\
\hline Geothermal heat flow ${ }^{3}$ & $h_{f}$ & $\mathrm{~W} / \mathrm{m}^{2}$ & 0.070 \\
\hline
\end{tabular}

${ }^{1}$ ARPAV, 2017

${ }^{2}$ UNI 11466, 2012 (values selected on the base of geology and hydrogeology information from cutting)

${ }^{3}$ UNMIG, 2017

values, it leads to completely inaccurate results at 5, 10 and $15 \mathrm{~m}$ depth (see Figure 6).

2. Ground temperature at $5 \mathrm{~m}$ depth, on the contrary, seems to be following a sinusoidal behaviour with an average of $15^{\circ} \mathrm{C}$, amplitude $4^{\circ} \mathrm{C}$ (which corresponds to an ambient amplitude of $6^{\circ} \mathrm{C}$ ) and a time of minimum of 30 days. By using such values, it leads to quietly accurate results of the lower part of the sinusoidal wave at $2 \mathrm{~m}$, while the wave at 10 and $15 \mathrm{~m}$ depth appears time shifted (see Figure 7). 

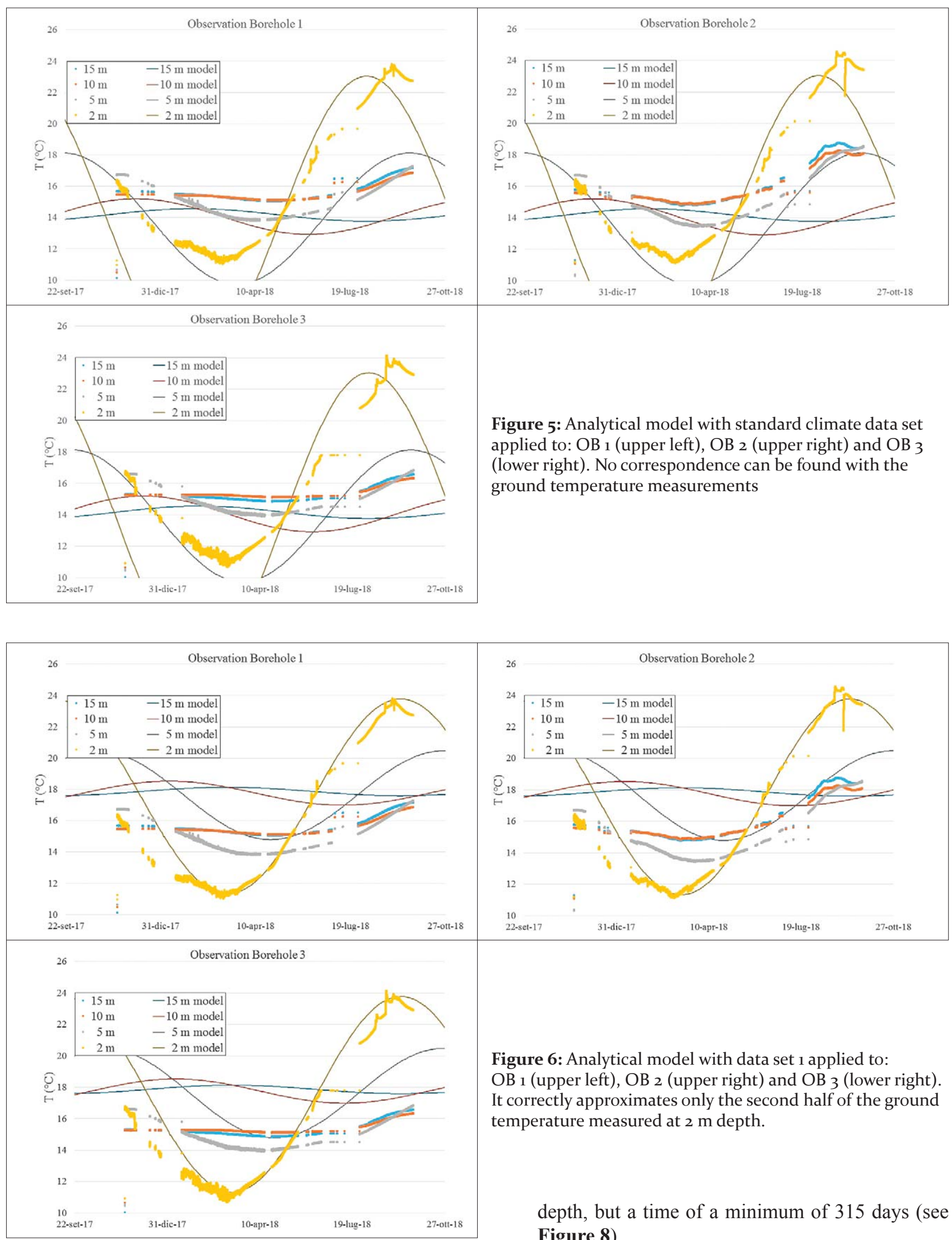

Figure 5: Analytical model with standard climate data set applied to: $\mathrm{OB}_{1}$ (upper left), $\mathrm{OB}_{2}$ (upper right) and $\mathrm{OB}_{3}$ (lower right). No correspondence can be found with the ground temperature measurements

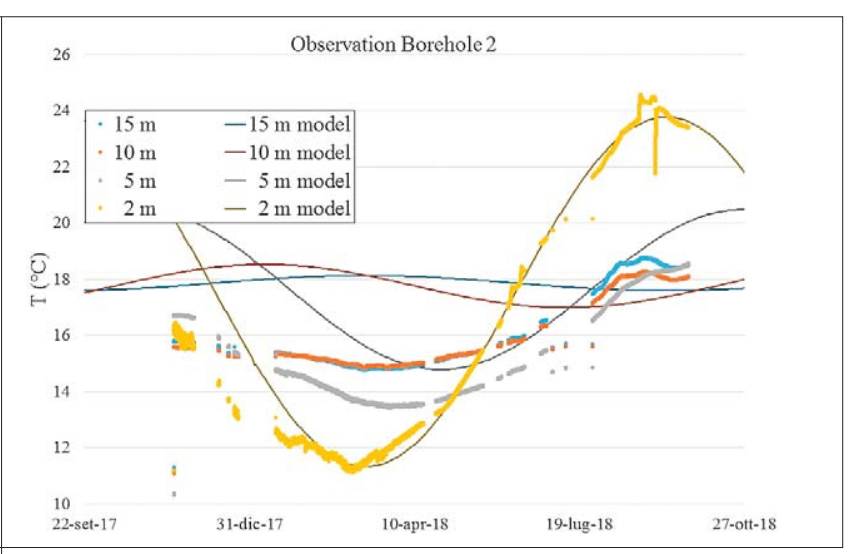

Figure 6: Analytical model with data set 1 applied to:

$\mathrm{OB} 1$ (upper left), $\mathrm{OB}_{2}$ (upper right) and $\mathrm{OB}_{3}$ (lower right). It correctly approximates only the second half of the ground temperature measured at $2 \mathrm{~m}$ depth.

depth, but a time of a minimum of 315 days (see Figure 8).

The Root Mean Square Error (RMSE) between model

3. Ground temperature at 10 and $15 \mathrm{~m}$ depth, finally, seems to be following a sinusoidal behaviour with the same average of ground temperature at $5 \mathrm{~m}$ results and measurements was calculated. The four different data sets of initial parameters were used to verify how well the analytical model fits with measured data: 

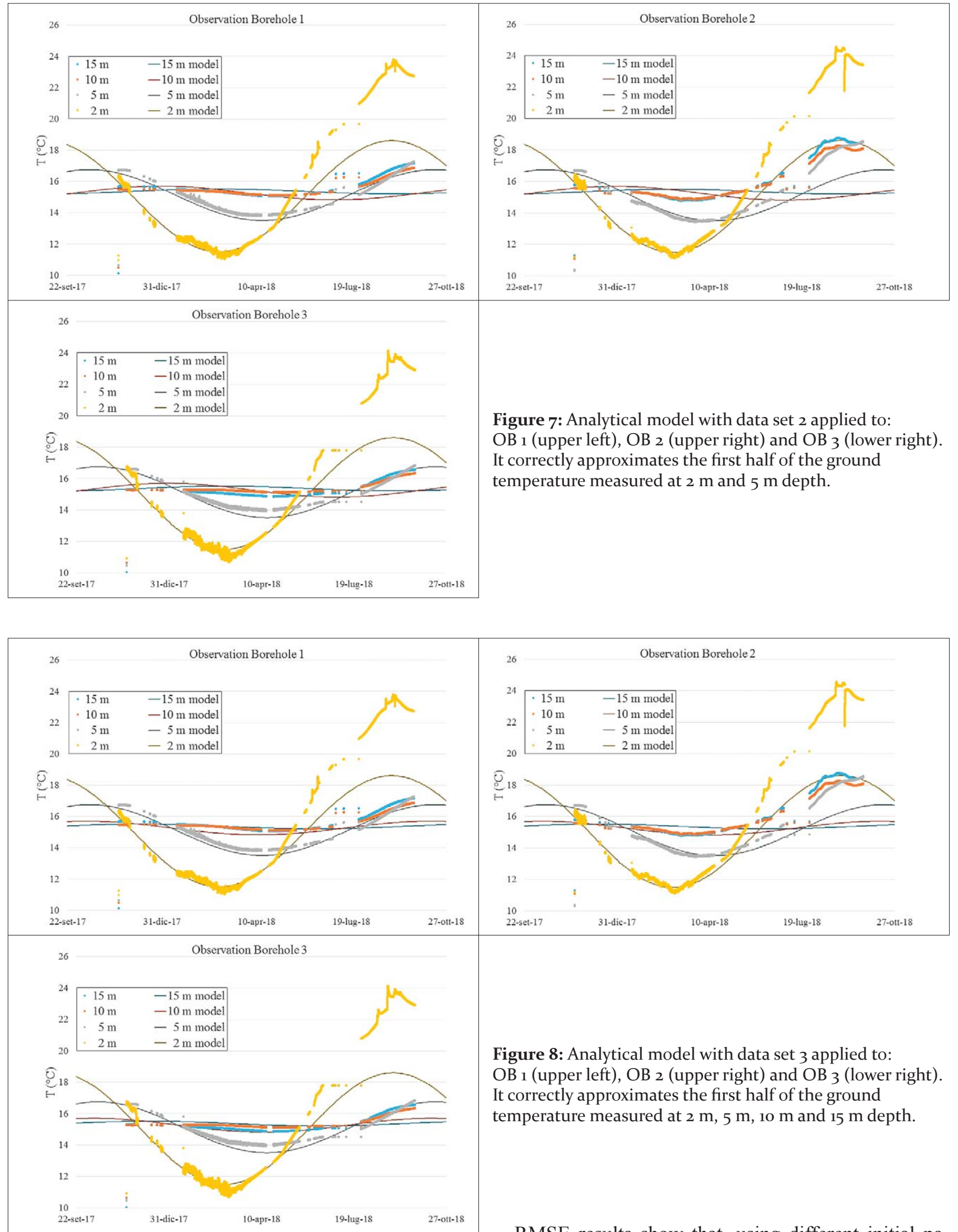

Figure 7: Analytical model with data set 2 applied to: $\mathrm{OB} 1$ (upper left), $\mathrm{OB}_{2}$ (upper right) and $\mathrm{OB}_{3}$ (lower right). It correctly approximates the first half of the ground temperature measured at $2 \mathrm{~m}$ and $5 \mathrm{~m}$ depth.

Figure 8: Analytical model with data set 3 applied to: $\mathrm{OB} 1$ (upper left), $\mathrm{OB}_{2}$ (upper right) and $\mathrm{OB}_{3}$ (lower right). It correctly approximates the first half of the ground temperature measured at $2 \mathrm{~m}, 5 \mathrm{~m}, 10 \mathrm{~m}$ and $15 \mathrm{~m}$ depth.

RMSE results show that, using different initial paStandard Climate Data Set (see Figure 5), Data Set 1 (see Figure 6), Data Set 2 (see Figure 7) and Data Set 3 (see Figure 8).

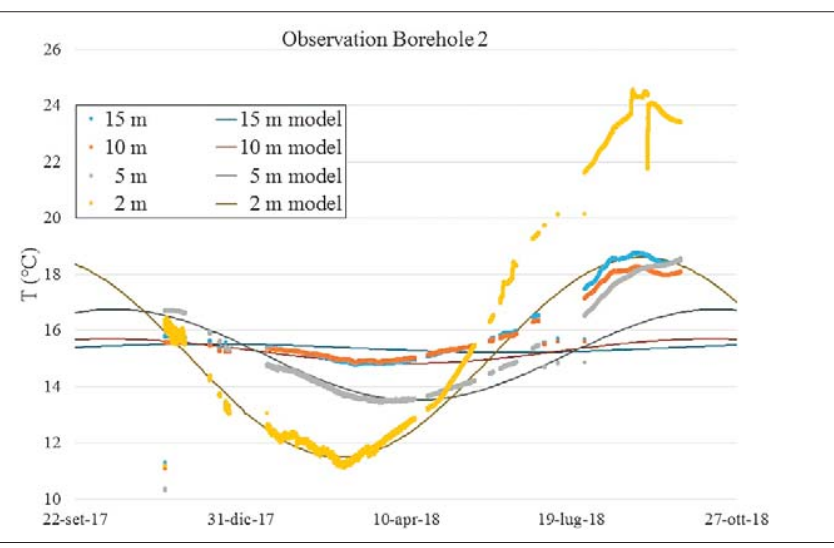

rameters from the standard climate data set of Tribano, the first part of the ground temperature measurements (roughly up to the month of May 2018) can be approximated by the analytical model, of sinusoidal behaviour, 
Table 4: Root Mean Square Error between model results and measurements at four Depths (D) in three Observation Boreholes (OB)

\begin{tabular}{|c|c|c|c|c|c|c|c|c|c|c|c|c|c|c|c|c|c|}
\hline \multicolumn{2}{|c|}{ RMSE } & \multicolumn{4}{|c|}{ CLIMATE DATA SET } & \multicolumn{4}{|c|}{ DATA SET 1} & \multicolumn{4}{|c|}{ DATA SET 2} & \multicolumn{4}{|c|}{ DATA SET 3} \\
\hline$O B$ & $D(\mathrm{~m})$ & 15 & 10 & 5 & 2 & 15 & 10 & 5 & 2 & 15 & 10 & 5 & 2 & 15 & 10 & 5 & 2 \\
\hline$O B 1$ & & 1.61 & 1.77 & 3.03 & 4.24 & 2.45 & 2.41 & 2.18 & 1.11 & 0.75 & 0.70 & 0.27 & 2.23 & 0.70 & 0.49 & 0.27 & 2.23 \\
\hline$O B 2$ & & 2.43 & 2.44 & 2.70 & 4.32 & 2.51 & 2.49 & 1.99 & 1.07 & 1.65 & 1.55 & 0.92 & 2.61 & 1.61 & 1.26 & 0.92 & 2.61 \\
\hline OB3 & & 1.29 & 1.62 & 3.10 & 4.24 & 2.73 & 2.51 & 2.30 & 1.05 & 0.64 & 0.53 & 0.31 & 2.22 & 0.57 & 0.32 & 0.31 & 2.22 \\
\hline
\end{tabular}

of Equation 1. The discrepancy between the climate data and ground temperature measurements should be explained by heat waves of anthropic origin (for example considering a heat loss to the ground, and subsequent storage, due to the works for the installation of the BHE field and the parking lot). Further investigations will be approached by a multi-year measurement campaign, with more stable thermal conditions. On the contrary, the second half of the measured temperature (starting from May 2018) does not follow the model anymore. Temperature in all points is increasing, several degrees higher than the expected temperature by the analytical model, phenomenon particularly evident at $2 \mathrm{~m}$ depth. An anomalous heat pulse from the ground surface should be added, with subsequent damping with depth. The most probable explanation relies on the cover material used for the parking lot, black asphalt, subjected to sun radiation all day, especially in the summer season (see Figure 3). The past summer (June-September), there were 72 sunny days ( $75 \%$ of the total), with an average daily temperature of $27^{\circ} \mathrm{C}$ and peaks of $37^{\circ} \mathrm{C}$. However, the daily impact is supposed to disappear at a depth of $1.5-2.0 \mathrm{~m}$, so the heat wave behaviour measured in the ground cannot be fully explained at the moment and further investigations will be undertaken. OB 2 is the nearest $\mathrm{OB}$ to the BHE 8, and so the most affected by heat pump operations heat pump operations. From May to September, the dual source heat pump worked regularly, in cooling mode, thus injecting heat to the ground. In OB 2 , this effect is clearly visible, with temperature values at 5,10 and $15 \mathrm{~m}$ depth higher of around $1^{\circ} \mathrm{C}$ than values measured in OB 1 and OB 3. Temperature measurements in the period $11-27$ July should not be taken into consideration, since the monitoring system faced unexpected issues, which were later solved. Measured values of OB 2 will be useful for the quantification of penetration diameters of heat pulse from CBHE to the undisturbed ground. In the winter period, the work of DSHP was more discontinuous, being at the very initial and testing phase. Therefore, less evidence of geothermal heat pump operations could be found in the thermal footprint measured underground. Nonetheless, a decrease of $0.5^{\circ} \mathrm{C}$ from standard behaviour can be perceived at 5, 10 and $15 \mathrm{~m}$ depth from February 2018 to April 2018 in OB 2, which does not appear in OB 1 and OB 3. At $5 \mathrm{~m}$ depth, in $\mathrm{OB} 2$, the temperature reaches a minimum of $13.5^{\circ} \mathrm{C}$, while in $\mathrm{OB} 1$ and $\mathrm{OB} 3$ the minimum is no lower than $14^{\circ} \mathrm{C}$. The setup and testing phase of the monitoring sys- tem faced some unexpected issues. In particular, a Digital Multiplexer was present at the beginning of the monitoring, which burned and was replaced several times. It was observed that the circulating water was electrostatically charged and introduced electrical shocks into the system. The problem was solved by moving the system away from the wells and discharging the current to the ground. After some months, the control units started to show a series of anomalies, resulting in several locks. The problems repeated over a long period of time when the cause was finally detected in a $380 \mathrm{~V}$ three-phase transformer. This one was positioned next to the control unit and discharged the current on the metal bottom plate, which, in turn, was fixed to the UMTS for data transmission. The router carried the mass through the power supply to the control unit, effectively blocking it. The problem was solved by disconnecting the router power supply and transmitting data via LAN network. This case is an example of the fact that any monitoring system, even advanced, can present problems linked to the real conditions of use that were previously unthinkable and difficult to identify on-site.

\section{Conclusion}

This paper presented the practical aspects related to the installation of a temperature monitoring system with the aim of understanding thermal behaviour of underground subjected to the work of a prototype of a dual source heat pump connected to a field of shallow coaxial borehole heat exchangers. The setup of the monitoring system faced some problems linked to specific conditions of the test site, whose solution, presented in the paper, can help practitioners and BHE installers. The preliminary monitoring measurements of ground temperature evidenced a different behaviour from the one expected by applying the standard climatic model. The thermal impact on the ground of anthropic origin seemed to be affecting the ground thermal behaviour for the time period considered, resulting in an average temperature value higher and an amplitude value lower than the ones obtained by the analytic climate model. The most probable explanation for this phenomenon relies on the black asphalt of the parking lot, which substituted natural ground at the surface level. After the ignition of the dual source heat pump (in winter mode: preliminary testing, and in cooling mode: working at full capacity), the thermal effect to the ground could have been detected by the 
monitoring borehole located $1 \mathrm{~m}$ away from one BHE. On the other hand, it seems that the heat wave did not have a significant effect on the ground inside the BHE field. Long term, multiyear, monitoring will be useful to appreciate the broad effect of the working of the system on the volume of the ground interested by the presence of BHEs. Further analysis on the records of temperature, flow rate of the circulating water in the pipe circuit and the heat pump parameters will be aggregated to the ground temperature data for a comprehensive assessment of the thermal behaviour of the shallow geothermal field. Moreover, they will be used for the validation of the operative model of the innovative dual source heat pump and its coupling to the geothermal reservoir.

\section{Acknowledgements}

The research work presented in this paper was supported by the research project GEOTeCH (www.geotech-project.eu), co-funded by the European Community Horizon 2020 Program for European Research and Technological Development (2014-2020) - Grant Agreement 656889. Moreover, concerning the pilot site, the authors would like to thank Prof. Carla Montagud (Universidad Politecnica de Valencia) and Prof. Davide del Col (University of Padua) for their invaluable support in the geometry definition. Finally, the authors would like to thank the companies Groenholland (Dr. Guus Van Gelder) and HIREF (Eng. Alessandro Zerbetto and Eng. PhD. Giulio Busato) for the professionalism and kindness in implementation of practical aspects related to installation, trial and maintenance.

\section{References}

\section{Published works (papers, books, proceedings):}

Aresti L., Christodoulides P. and Florides G. (2018): A review of the design aspects of ground heat exchangers, Renewable and Sustainable Energy Reviews, 92, 757-773.

Badenes, B., Magraner T., de Santiago C., de Santayana F.P. and Urchueguía J.F. (2017): Thermal behaviour under service loads of a thermo-active precast pile, Energies, 10(9):1315.

Baggs S.A. (1983): Remote prediction of ground temperature in Australian soils andmapping its distribution, Solar Energy 30: 351-366, http://dx.doi.org/10.1016/0038-092X (83)90189-5.

Cazorla-Marín A., Montagud C., Corberán J.M., Tinti F. and Focaccia S (2018): Upgrade of the B2G dynamic geothermal heat exchanger model: Optimal location of the ground nodes. In: Proceedings of International Ground Source Heat Pump Association Conference, Stockholm, September 2018 .

Focaccia S., Tinti F., Monti F., Amidei S. and Bruno R. (2016): Shallow geothermal energy for industrial applications: A case study, Sustainable Energy Technologies and Assessments, 16, 93-105.
Giambastiani B.M.S., Tinti F., Mendrinos D. and Mastrocicco M. (2014): Energy performance strategies for the large scale introduction of geothermal energy in residential and industrial buildings: The GEO.POWER project, Energy Policy, 65, 315-322.

Eskilson, P. (1987): Thermal Analysis of Heat Extraction Boreholes. Department of Mathematical Physics, University of Lund, Sweden (Ph.D. dissertation).

Hähnlein S., Bayer P., Ferguson G. and Blum P. (2013): Sustainability and policy for the thermal use of shallow geothermal energy, Energy Policy, 59, 914-925.

Florides G., Pouloupatis P.D., Kalogirou S., Messaritis V., Panayides I., Zomeni Z. Partasides G., Lizides A., Sophocleous E. and Koutsoumpas K. (2013): Geothermal properties of the ground in Cyprus and their effect on the efficiency of ground coupled heat pumps, Renewable Energy, 49, 85-89.

Kurevija T. and Vulin D. (2010): Determining undisturbed ground temperature as part of shallow geothermal resources assessment. Rudarsko-geolosko-naftni zbornik, 22, 27-36.

Magraner, T., Montero A., Quilis S. and Urchueguia J.F. (2010): Comparison between design and actual energy performance of a HVAC-ground coupled heat pump system in cooling and heating operation, Energy and Buildings, 42, 1394-1401.

Montagud C., Corberán J.M, Montero Á. And Urchueguía and J.F. (2011): Analysis of the energy performance of a ground source heat pump system after five years of operation, Energy and Buildings, 43: 3618-3626.

Segalini A. and Carini C. (2013): Underground Landslide Displacement Monitoring: A New MMES Based Device. In: Margottini C., Canuti P., Sassa K. (eds) Landslide Science and Practice. Springer, Berlin, Heidelberg. DOI: https:// doi.org/10.1007/978-3-642-31445-2_11.

Segalini A., Chiapponi L., Pastarini B. and Carini C. (2014): Automated Inclinometer Monitoring Based on Micro Electro-Mechanical System Technology: Applications and Verification. In: Sassa K., Canuti P., Yin Y. (eds) Landslide Science for a Safer Geoenvironment. Springer, Cham. DOI: https://doi.org/10.1007/978-3-319-05050-8_92.

Tinti F., Kasmaee S., Elkarmoty M., Bonduà S. and Bortolotti V. (2018) Suitability Evaluation of Specific Shallow Geothermal Technologies Using a GIS-Based Multi Criteria Decision Analysis Implementing the Analytic Hierarchic Process, Energies, 11(2), 457.

Tinti F., Pangallo A., Berneschi M., Tosoni D., Rajver D., Pestotnik S., Jovanovic D., Rudinica T., Jelisic S., Zlokapa B., Raimondi A., Tollari F., Zamagni A., Chiavetta C., Collins J., Chieco M., Mercurio A., Marcellini F., Mrvaljević D. and Meggiolaro M. (2016): How to boost shallow geothermal energy exploitation in the Adriatic area: the LEGEND project experience, Energy Policy, 92: 190-240.

Tinti, F., Barbaresi, A., Ferrari, M., Elkarmoty, M., Torreggiani, D., Tassinari, P. and Bonduà, S. (2017): Experimental calibration of underground heat transfer models under a winery building in a rural area, Rudarsko Geolosko Naftni Zbornik, 32(3): 15-22. 
Ruiz Calvo F., De Rosa M., Acuna J., Corberan J.M. and Montagud C. (2015) Experimental validation of a short-term Borehole-to-Ground (B2G) dynamic model, Applied Energy, 140: 2010-223.

\section{Internet sources:}

URL: http://www.capitindustria.eu/Scheda-Informazioni-generali_1_3_22.html [Last Access: September 18th, 2018]

URL: http://www.geotech-project.eu

\section{Sources from professional archives:}

ARPAV - Dipartimento Regionale per la Difesa del Territorio (2017): Servizio meteorologico, misure giornaliere di Temperatura aria a $2 \mathrm{~m}$ - media $\left({ }^{\circ} \mathrm{C}\right)$ "ARPAV - Department for Territory Protection of Veneto Region (2017): meteorological service, daily measurements of air temperature at 2 $\mathrm{m}$ eight - average $\left({ }^{\circ} \mathrm{C}\right) "$.

Gazzetta Ufficiale della Repubblica Italiana (1984): Norme per agevolare l'acquisizione da parte del Servizio geologico della Direzione generale delle miniere del Ministero
dell'Industria, del commercio e dell'artigianato di elementi di conoscenza relativi alla struttura geologica e geofisica del sottosuolo nazionale, Estratto da: Gazzetta ufficiale della Repubblica Italiana del 17-8-1984, n. 226, legge 4 agosto 1984, n. 464. "Official Gazette of the Italian Republic (1984): Rules to facilitate the purchase by the Geological Service of the Directorate General of the mines of the Italian Ministry of Industry, Commerce and Crafts of information related to the geological and geophysical structure of the national subsoil, Excerpt from: Official Journal of the Italian Republic of 17-8-1984, n. 226, law 4 August 1984, n. 464"

Pomarè Montin D. (2017): Add "hydro-geological study. Closed-lopp geothermal Plant. Municipality of Tribano"

UNI 11466 (2012): Sistemi geotermici a pompa di calore. Requisiti per il dimensionamento e la progettazione "UNI1466 (2012): Heat pump geothermal systems: Design and sizing requirements"

UNMIG (2017): Zonazione geotermica del territorio italiano. 24 pp. "UNMIG (2017): Geothermal zoning of Italian territory. 24 pp."

\section{SAŽETAK}

\section{Praćenje potpovršinske temperature za uporabu koaksijalnih geotermalnih izmjenjivača - praktični aspekti i glavni problemi u prvim godinama mjerenja}

Plitka, potpovršinska, temperatura (na dubinama plićim od $50 \mathrm{~m}$ ) nije konstatna, niti u prostoru, niti vremenu. Takve promjene posljedica su utjecaja toplinskih „pulseva” različitoga podrijetla poput Sunčeva, geotermalnoga ili ljudskoga. Točna procjena temperature ključni je čimbenik kod planiranja energetskih sustava temeljenih na plitkoj geotermalnoj energiji. U takvim projektima, temeljenim na izmjenjivačima topline u plitkim bušotinama, potpovršinska je temperatura promjenjivija, što utječe na iznos pridobivanja topline, tj. utiskivanja fluida. Praćenje takvih promjena važno je stoga kod svih projekata toplinskih izmjenjivača vezanih uz plitka geotermalna ležišta. U radu je prikazan praktičan oblik toga, ali i glavni problemi koje je moguće susresti tijekom instaliranja, testiranja ili uporabe potrebne geotermalne opreme. Dan je primjer polja u kojemu je smješteno osam koaksijalnih izmjenjivača topline, 30 metara dugačkih te povezanih s prototipom uređaja dvostruke toplinske crpke (zračne i dubinske).

\section{Ključne riječi:}

geotermalna energija, potpovršinska temperatura, bušotinski izmjenjivač topline, praćenje

\section{Authors' contribution}

Eng. PhD Francesco Tinti participated in the definition of monitoring system geometry and in the installation and testing phases. He faced all issues related to the electronic problems. He is the main contributor of this paper. Eng. Andrea Carri realized the electronics of the monitoring system and participated in the installation and testing phases. Moreover, he faced all major issues related to the electronic problems and contributed in writing the paper. Eng. PhD Sara Kasmaee participated in the installation phase, data analysis and paper modifications. Eng. Alessandro Valletta helped solve the issues related to the electronic problems and contributed in writing the paper. Eng. PhD Andrea Segalini supervised the electronic work and reviewed the paper. Eng. PhD Stefano Bonduà participated in the data analysis and reviewed the paper. Prof. Villiam Bortolotti is the scientist responsible for the GEOTeCH Project for the University of Bologna group and reviewed the paper. 